Kinestetik : Jurnal Ilmiah Pendidikan Jasmani 5 (2) (2021)
Kinestetik : Jurnal Ilmiah Pendidikan Jasmani
https://ejournal.unib.ac.id/index.php/kinestetik/index
DOI : 10.33369/jk.v5i2.16016

\title{
TACTICAL ACTION PROFILE OF INDONESIAN FUTSAL GOALKEEPERS
}

\author{
Desrio Windoro $^{1^{*}}$, Rekha Ratri Julianti ${ }^{2}$, Intan Primayanti ${ }^{3}$ \\ ${ }^{1}$ Physical Education Study Program, FKIP, Universitas Dehasen Bengkulu \\ ${ }^{2}$ Physical Education, Health and Recreation Study Program, FKIP, Singaperbangsa University of \\ Karawang \\ ${ }^{3}$ Sport Education and Helath Study Program, FKIP, Mandalika Education of Mataram University
}

\section{Article Info}

Article History :

Received : May 2021

Revised : June 2021

Accepted : June 2021

Available online : June 2021

\section{Keywords:}

Profile, Tactical Action, Goalkeeper

\begin{abstract}
This research aims to describe the overall tactical action profile of the national goalkeeper during the match. This research used observational research methods. The population of this study were 12 futsal teams which entered the national round, consisting of 8 male futsal teams and 4 female futsal teams with a total sample of 16 male goalkeepers and 8 female goalkeepers, total of 24 goalkeepers as samples. The results of this study show that the tactical action profile of the national goalkeepers futsal in the Nusantara Futsal League as a whole. The goalkeeper s gave a hand gesture by pointing the opponent to guard the designated opponent as much as $60.35 \% .5 \%$, the goalkeeper s thrown a short ball to the defender by $37.28 \%$ goalkeeper, the goalkeeper s stopped the ball with his hands, when the ball came in the area behind his defense by $31.68 \%$, the goalkeeper s stopped the ball with his feet, when the ball came in the back area defense 306 times $(31.29 \%)$, when the corner kicked on the left or right side, the goalkeeper s instructed the player to cover as many goals as possible on his left or right side 237 times (24.3\%), the goalkeeper away from the goal line to catch or ward off the ball carried out by the goalkeeper 81 times $(8.28 \%)$, the goalkeepers caught the ball then kicks it directly towards the opposing team's goal 56 times ( 5.73\%), the goalkeeper catches the ball and kicks it directly towards the opposing team's goal 27 times $(4.77 \%)$, and the goalkeeper defends the defender 271 times $(27.6 \%)$. It be concluded that national goalkeepers tactical action profile in Indonesian Nusantara Futsal League dominantly that the goalkeepers used sign by her / his hand to show theirs affairs nearby to the goal.
\end{abstract}

\begin{tabular}{llr}
\hline Corresponding address & $:$ Jln. Meranti Raya No.32 Sawah Lebar & ISSN 2685-6514 (Online) \\
Email & $: \underline{\text { desrio25@ unived.ac.id }}$ & ISSN 2477-331X (Print)
\end{tabular}




\section{INTRODUCTION}

In Indonesia, futsal is an inseparable part of the PSSI (Indonesian Football Association). Futsal used to be under the auspices of BFN (National Futsal Agency), which is an agency that has built and developed futsal in Indonesia. However, in 2014, BFN was no longer the body responsible for futsal in Indonesia, but a new association was formed called the Indonesian Futsal Association (AFI). But AFI is still under PSSI. AFI has the same task as BFN, namely building and developing futsal in Indonesia. AFI also continues the league that has been formed by BFN since 2006. The league which was originally called the Indonesian Futsal League (IFL) changed to the 2016 Futsal Super League (FSL) and is now changed to the Pro Futsal League (PFL). However, before entering or participating in the pro futsal league 2020, AFI held a competition called the archipelago league, where the competition, which is held once a year, revolves mainly in every province in Indonesia. Then a big 34 match was held, each of which was divided into four regional clubs and then divided into 8 national round teams for men's teams and 4 national round teams for women, and from these 8 men's teams 4 best semifinalist teams were selected. Meanwhile, from the women's team, the best 2 teams were taken from those teams to be promoted to the Indonesian professional league.

Halim (2011) stated that the futsal game is a type of football game that is played on a field smaller in size. Apart from the 5 main players, each team is also allowed to have a reserve player. Unlike other indoor soccer games, the futsal field is restricted a line, not a net or a board. Similar to football, futsal also has a position in the game, namely goal keeper, anchor, flank and pivot. These positions are not static, they often rotate because of the dynamic and fast nature of playing futsal. Regarding this, Lhaksana (2011) explains as follows: Futsal is a very fast and dynamic game. In terms of the relatively small pitch there is almost no mistake. Therefore, cooperation between players is needed through accurate passing, not trying to pass the opponent.

The goalkeeper is a player who is trusted to guard the goal from an opponent's attack. So that this position is the last defense in futsal and a very important position in defense. Goalkeepers must have good technical and tactical skills that aim to improve the ability to anticipate the ball. Luxbacher (2011) states that a goalkeeper is the most important player in the futsal team. The goalkeeper provides the team's last line of defense and must master a range of skills entirely different from those used by field players.

"Modern futsal goalkeepers are much more important than football goalkeepers who have a role only to protect the goal from goals, while modern futsal goalkeepers must anticipate situations and participate actively in the game" (Hermans \& Engler 2011: 41). If in conventional football a goalkeeper is often able to take a break between one attack and the next, in futsal a goalkeeper can hardly rest or relax for a moment. The attacks keep coming again and again " (Timo, 2011:97).

According to Vic and Lainer (2011:36)there are four positions to play in futsal games: kipper, anchor, flank, and pivot. Mulyono (2014:2) stated that Futsal can be defined as a sports game played by two different teams, each team consisting of five players who play 
matches in two rounds. Woitalla (2011) stated that a goalkeeper who does a good job of managing the team and mobilizing the players in a certain area, helps his teammates prepare for the opponent's attacks while keeping themselves alert. Such organization occurs even when the goalkeeping team has the ball. The goalkeeper keeps in touch with the players closest to him. The goalkeeper must anticipate where the problem is coming from and must ensure that there are enough players in the area to prevent or quickly close down threats. It is the responsibility of the goalkeeper to monitor and direct the game. Because the goalkeeper is not directly involved in the action, he can see what's going on and can provide clarity about where things can develop. According to Kramer (2012:7) there are four components that a futsal goalkeeper must have. these components are: technical, tactical, physical, and psychological.

In game, even a solid defense will suffer a momentary drift in concentration. When that happens, a goalkeeper may find himself face-toface with an opponent. The feeling of helplessness usually permeates when the ball is at the feet of the attacker. Great goalkeepers don't wait for the attackers to find their footing, but they rush out and narrow the corners to force the attackers into doing difficult shots. A goalkeeper who can be relied on during his vulnerable moments will build confidence in the team to deal with chaoticsituations. Goalkeepers sacrifice their bodies for the good of the teams, they often earn respect from their teammates.

In the explanation of the role of the goalkeeper above, it can be seen that the role of the goalkeeper has a considerable influence in a match. There are several research results related to goalkeepers. Andrzej et al. (2010) The Efficiency Model of Goalkeeper Actions in Soccer presents a cognitive model that describes the efficiency of the goalkeeper's actions in soccer based on his observation of playing in matches selected from the final of Euro 2008. The observation method used in this study. The games of the two goalkeepers were analyzed in seven football matches in the Euro Championship which took place in Portugal in 2008. Data is recorded on the writer's observation form. Activity, effectiveness and reliability during offensive and defensive actions are the subject of this examination. It is revealed that most of the goalkeeper's action is aimed at taking control of the field of play or maintaining possession of the ball; creating goal scoring opportunities represents only a fraction of an offensive action. Defensive action is generally performed on an individually basis and highest reliability is reported when catching the ball. A goalkeeper action efficiency model should be used to create a game model for players who represent a lower level of competition for the sport to increase the effectiveness of their play.

Another study by Franco et al. (2014) analyzed that the existing interactions between Futsal goalkeeper behavior and different variables (action, playing area, goal-block or goal-mistake, game and team situations). This research has used methodology and observation, because it is one of the choices of scientific study of behavior, as much as in real situations and in controlled situations. Results show that in shots on goal, $76.5 \%$ of them were intervening goalkeepers, in positional attack situations (54\%), with incidents in game between fields (L-39\%, R-33\%) and became more important technical action $(33.7 \%)$. Therefore, a correlation is 
observed between the goalkeeper's action and the zone in which the opponent shoots, between the action taken by the goalkeeper and the goal (success-block / goal-mistake), and between the action and belonging to a particular team.

Vicente-Vila1 and Lago-Peñas (2016) The aim of this study was to identify which variable is the best predictor of success in ball possession when controlling for space and taskrelated indicators, situational variables and goalkeeper participation as regular or reserve field players (5 vs 4 or 4 vs 4 ). The sample consisted of 326 possession situations according to the 31 matches played by teams from the Spanish Futsal League during 2010-2011, 2011-2012 and the 2012-2013 season. Multidimensional qualitative data obtained from 10 ordered categorical variables was used. Data were analyzed using chi-square analysis and multiple logistic regression analysis. Overall, the highest ball possession effectiveness was achieved when the goalkeeper participated as a regular field player ( $\mathrm{p}$ $<0.01$ ), duration of possession ball was less than 10 seconds ( $p<0.01)$, possession of the ball ended in the penalty area $(\mathrm{p}<0.01)$. ) and low defensive pressure $(\mathrm{p}<0.01)$. The information obtained about the relative tactical effectiveness of offensive play can be used to improve goal scoring abilities and prevent opponent attacks.

Bueno et al. (2018) The purpose of this study was to analyze the organization of futsal players on the field in different categories when attacking and defending, in interception and shots on goal situations. Track of 89 players from under 15 category, 102 players from under 18 category, and 110 professional players, during official matches. The spread, surface area, and distance of the Euclidians between team centroids are measured to represent the distribution of futsal players on the field. Variables were analyzed during each opensive and depensive sequence, and during shot-on-goal and interception situations, with and without the participation of outfield goalkeeping players. While the players were attacking, all categories presented a wider range and surface area, compared to current defensive values $(\mathrm{P}<0.01)$. Among the categories, the results showed lower values at spread and area for younger players $(\mathrm{P}<0.01)$. The results of the spread, surface area, and distance between team centroids show different forms of organization for each category in specific shot-on-goal and interception situations.

Moura et al. (2011) The purpose of this study was to measure and analyze the professional futsal team in organizing matches on the field in shots on goal and handling situations. Twodimensional coordinates of 22 player positions were obtained during the match between Brazil and Paraguay using a computational tracking system. Team organization in 58 specific shot-on-goal situations and 120 tackles was analyzed. The variables measured were the team coverage area and the distance between the team centroids. The results showed that the defense area of the defense team was larger $(\mathrm{p}<0.01)$ when the tackle was carried out $(47.7 \pm 37.8 \mathrm{~m} 2)$ than when the team experienced shots on goal (30.7 $\pm 28.0 \mathrm{~m} 2$ ). The mean distance between centroids was greater $(\mathrm{p}<0.01)$ in shots on goal $(5.2 \pm 2.7 \mathrm{~m})$ than in handling situations. These results can provide valuable insights for the trainer.

One of the unique realities of being a goalkeeper is the fact that a goalkeeper can save a game but it is almost impossible for a goalkeeper to win a game. But the truth is goalkeepers can't save a game alone, they need field 
players to play well and great goalkeepers are willing to do whatever it takes to help the field players become the best. Goalkeepers are vocally demanding when the players make mistakes but minutes later they are not eager to pay tribute to the same players. By managing the players, the goalkeeper puts the team in a position to be successful. The communication of a goalkeeper is very important. When they communicate with players there is rarely time on their side. The best goalkeepers are able to communicate effectively by saying less because they focus on the details of the match relating to the right moment. Goalkeepers play to develop their tactical skills.

Previous research has discussed a lot on the technical part of the four competencies of a goalkeeper. The other three are physical, tactical, and psychological. The tactical component is less of a concern for researchers to be used as study material in research even though the tactical competence in the form of goalkeeper behavior is crucial during matches.

Tactical action is the ability of a goalkeeper provides tactics and the goalkeeper had so many chances to play in the game and influenced teammates. When a goalkeeper receives the ball they are able to make a decision; keep the ball at the keeper's feet to slow down play or distribute quickly to build attacks. This decisionmaking process directly affects the game. When a goalkeeper makes a big save the goalkeeper has to decide how to respond. The goalkeeper can jump to his feet and run the team to play. The top of 8 men's and top 4 women's national futsal league goalkeepers in the archipelago in Indonesia certainly have tactical skills that goalkeepers usually do in matches. The national futsal team, which is included in the 2019 Indonesian archipelago league, is a team that has gone through a long qualifying round and a rigorous selection of players from each region spread across Indonesia. The absence of a special study in Indonesia that raises the tactical action of futsal goalkeepers when competing, which is usually done by national goalkeepers, is an interesting thing to investigate.

\section{METHODS}

This study used an observational research method. Descriptive observational is research that aims to describe an event. The research design used was cross sectional (Susilo and Suyanto, 2015). In crosssectional measurements, researchers make observations or measurements of variables at certain times. The observed subjects were observed only once and the measurement of the subject variables was carried out at the time of the examination. So, in the cross sectional study, the researcher did not follow up on the measurements that were taken. The cross-sectional design is a design that can be used for descriptive research. Sugiyono (2014) says that descriptive research is research conducted to determine the existence of independent variables, either one or more variables (independent variables) without making comparisons or looking for the relationship between variables with each other.

The population of this study were 12 Indonesian Futsal League teams in 2019 that entered the national round, consisting of 8 male futsal teams and 4 female futsal teams with a total sample size of 16 male goalkeepers and 8 female goalkeepers, so a total of 24 goalkeepers were sampled. However, from the 24 goalkeepers, there were two players who were not played during the semi-final 
round. The sample is the members that reflect the characteristics of the population. According to Sugiyono (2014) if the subject is less than 100 people, all of them should be taken, if the subject is large or more than 100 people can be taken $10-15 \%$ or $20-25 \%$ or more. Because the number of population subjects in this study were 24 people where the number was less than 100 people, all population subjects were taken as samples. So that the sampling technique used is total sampling or saturated sampling, which is a sampling technique when all members of the population are used as samples. So the sample in this study amounted to 24 people.

\section{RESULT}

\section{National Goalkeeper of Tactical Action Profile Based on Dimension Decision}

Table 1. Recapitulation of National Goalkeeper Tactical Action Profiles in terms of the dimensions of Decision Making at the 2019 Nusantara Futsal League Match

\begin{tabular}{|c|c|c|c|}
\hline No & Aspect & Amount & $\%$ \\
\hline 1 & $\begin{array}{l}\text { When the ball is in the } \\
\text { opposing team, the } \\
\text { goalkeeper must } \\
\text { always look for an } \\
\text { opening so he can see } \\
\text { the ball }\end{array}$ & 691 & $54.5 \%$ \\
\hline 2 & $\begin{array}{l}\text { When the ball is on the } \\
\text { goalkeeper, the } \\
\text { goalkeeper throws the } \\
\text { short ball at the } \\
\text { defender }\end{array}$ & 365 & $37.28 \%$ \\
\hline 3 & $\begin{array}{l}\text { The goalkeeper stops } \\
\text { the ball with his hand } \\
\text { when it comes to the } \\
\text { back of his defense }\end{array}$ & 286 & $31.68 \%$ \\
\hline 4 & $\begin{array}{l}\text { When a corner kicks } \\
\text { the goalkeeper } \\
\text { positions himself } \\
\text { between the two } \\
\text { players who are } \\
\text { approaching the } \\
\text { direction of the ball }\end{array}$ & 306 & $31.29 \%$ \\
\hline 5 & $\begin{array}{l}\text { When a shot is weak } \\
\text { from the opponent the } \\
\text { keeper tries to catch it } \\
\text { with both hands }\end{array}$ & 242 & $30.52 \%$ \\
\hline
\end{tabular}

From table above it can be explained that the profile of the tactical action of the national futsal goalkeeper in terms of decision-making dimensions in the Indonesian archipelago futsal league match in 2019 the most tactical action taken by goalkeepers is when the ball is in the opposing team, the goalkeeper must always look for gaps in order to be able to. The goalkeeper saw the ball 691 times (54.5\%), When the ball is at the goalkeeper, the goalkeeper throws the short ball to the defender 365 times $(37.28 \%)$ done by the goalkeeper, the goalkeeper stops the ball by hand, when the ball arrives in the area behind the defense was taken by the goalkeeper 286 times (31.68\%), When the goalkeeper's corner kicked himself between the two players who approached the direction of the ball 306 times (31.29\%) were taken by the goalkeeper, When the shot was weak of the opponent the keeper attempted to catch with both hands 242 times (30.52\%). For more details, see chart 1 . below:

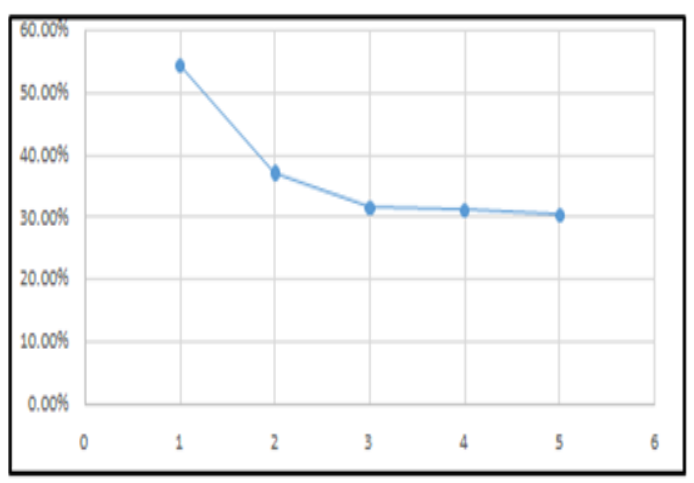

Fig 1. Graphic National Futsal Goalkeeper Tactical Action Profile in terms of Taking Dimensions

\section{The Profile of National Goalkeeper Tactical Actions in terms of Goalkeeper Order Dimensions in the Penalty Area in the 2019 Indonesian Archipelago Futsal League Match}


Table 2. National Goalkeeper of Tactical Action Profile in terms of Goalkeeper Order Dimensions in the Penalty Area

\begin{tabular}{clcc}
\hline No & \multicolumn{1}{c}{ Aspect } & Amount & \% \\
\hline 1 & $\begin{array}{l}\text { The goalkeeper gives a } \\
\text { hand signal by }\end{array}$ & & $60.35 \%$ \\
& $\begin{array}{l}\text { pointing at the } \\
\text { opponent as a signal to }\end{array}$ & & \\
& guard the designated \\
opponent & & \\
\hline 2 & $\begin{array}{l}\text { The goalkeeper uses } \\
\text { the word "left ready" } \\
\text { "night ready" in } \\
\text { commanding } \\
\text { teammates }\end{array}$ & & $34.23 \%$ \\
\end{tabular}

From the table 2 above, it can be explained that the profile of the national futsal goalkeeper's tactical actions in terms of the dimensions of the goal keeper's orders in the penalty area in the Indonesian archipelago futsal league match in 2019. The tactical action that most goalkeepers do is that the goalkeeper gives a hand symbol by pointing at the opponent as a signal to escorting the designated opponent 615 times $(60.35 \%)$ by the kipper. Goalkeepers used the word "left ready" "right ready" in commanding teammates 474 times $(34.23 \%)$ done by goalkeepers. For more details, it can be seen from the graph 2 . below:

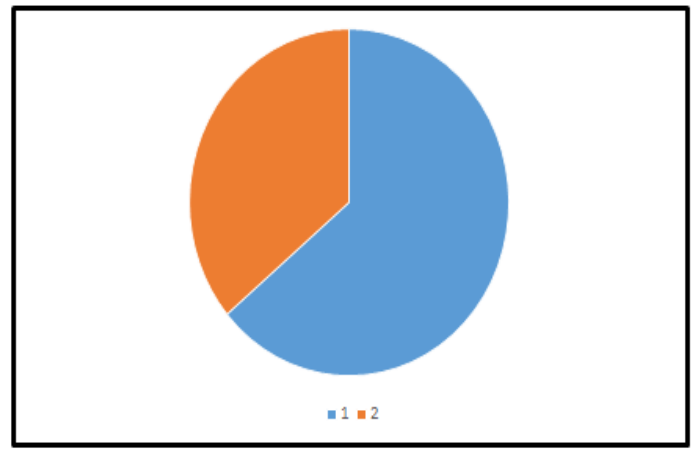

Fig 2. Graphic Profile of National Futsal Goalkeeper Tactical Action Judging from the Dimensions of Goalkeeper Orders in the Penalty Area
Profile of National Goalkeeper Tactical Actions in the 2019 Indonesian Archipelago Futsal League

The following is a description of the observation data on the 2019 Nusantara Futsal League, a combination of decision-making indicators and giving orders in the penalty area based on the largest percentage that is mostly carried out by national goalkeepers in the 2019 Indonesian Archipelago Futsal League.

Table 3. The Profile of National Goalkeeper Tactical Actions in the 2019 Indonesian Archipelago League is as follows:

\begin{tabular}{|c|c|c|c|}
\hline No & Indicator & Aspect & Percentace \\
\hline 1 & $\begin{array}{l}\text { communica } \\
\text { tion }\end{array}$ & $\begin{array}{l}\text { The goalkeeper } \\
\text { gives a hand } \\
\text { signal by pointing } \\
\text { at the opponent as } \\
\text { a signal to guard } \\
\text { the designated } \\
\text { opponent }\end{array}$ & $60.35 \%$ \\
\hline 2 & $\begin{array}{l}\text { The } \\
\text { goalkeeper } \\
\text { reads the } \\
\text { movement } \\
\text { of the ball }\end{array}$ & $\begin{array}{l}\text { When the ball is } \\
\text { in the opposing } \\
\text { team, the } \\
\text { goalkeeper must } \\
\text { always look for an } \\
\text { opening so he can } \\
\text { see the ball }\end{array}$ & $54.5 \%$ \\
\hline 3 & $\begin{array}{l}\text { Set the } \\
\text { tempo of } \\
\text { the match }\end{array}$ & $\begin{array}{l}\text { When the ball is } \\
\text { on the goalkeeper, } \\
\text { the goalkeeper } \\
\text { throws the short } \\
\text { ball at the } \\
\text { defender }\end{array}$ & $37.28 \%$ \\
\hline 4 & $\begin{array}{l}\text { Type } \\
\text { command }\end{array}$ & $\begin{array}{l}\text { The goalkeeper } \\
\text { uses the word } \\
\text { "left ready" "right } \\
\text { ready" in } \\
\text { commanding } \\
\text { teammates }\end{array}$ & $34.23 \%$ \\
\hline 5 & $\begin{array}{l}\text { The } \\
\text { goalkeeper } \\
\text { keeps away } \\
\text { from the } \\
\text { circle and } \\
\text { goal line }\end{array}$ & $\begin{array}{l}\text { The goalkeeper } \\
\text { stops the ball with } \\
\text { his hand when it } \\
\text { corners to the } \\
\text { back of his } \\
\text { defense }\end{array}$ & $31.68 \%$ \\
\hline 6 & $\begin{array}{l}\text { Corners for } \\
\text { opponents }\end{array}$ & $\begin{array}{l}\text { When the corner } \\
\text { kicks the } \\
\text { goalkeeper moves } \\
\text { himself between } \\
\text { the two players } \\
\text { who are } \\
\text { approaching the } \\
\text { direction of the } \\
\text { ball }\end{array}$ & $31.29 \%$ \\
\hline 7 & $\begin{array}{l}\text { Stop } \\
\text { shooting }\end{array}$ & $\begin{array}{l}\text { When a shot is } \\
\text { weak from the } \\
\text { opponent the } \\
\text { keeper tries to } \\
\text { catch it with both } \\
\text { hands }\end{array}$ & $30.52 \%$ \\
\hline
\end{tabular}


From table 3 above it can be explained that the 22 futsal goalkeepers in the Nusantara League in 2019 the tactical actions that goalkeepers mostly performed consecutively based on the percentage of the indicators were the goalkeeper giving hand signals by pointing to the opponent as a signal to guard the designated opponent 615 times or $(60.35 \%)$. When the ball is on the opposing team, the goalkeeper must always look for a gap so that he can see the ball is done by the goalkeeper 691 times $(54.05 \%)$. When the ball is at the goalkeeper, the goalkeeper throws the short ball at the defender. 365 or $(37.28 \%)$, the goalkeeper used the word "left ready" "right ready" in ordering a teammate 474 times or $(34.23 \%)$, the goalkeeper stopped the ball by hand, when the ball came in the area behind his defense 286 times or (31.68\%), when the goalkeeper's corner kicks himself between the two players who are approaching the direction of the ball 306 times or $(31.29 \%)$, When the goalkeeper's corner positions himself between the two players who approach the direction of the ball 306 times or (31.29\%), and when a weak shot from the opponent the keeper tries to catch with both hands 242 times or $(30.52 \%)$ it is taken by goalkeeper. For more details, see chart 3. below:

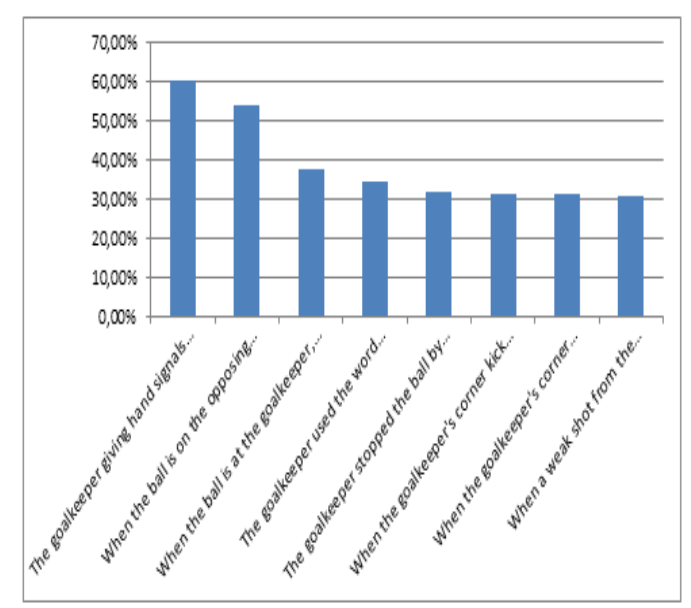

Fig 3. Graphic The Profile of National Goalkeeper Tactical Action in 2019 Indonesian Archipelago Futsal League

\section{DISCUSSION}

The discussion of the results of this study provides a further interpretation regarding the results of the data analysis that have been presented. Based on the results of the data above, three analysis discussion groups have been produced, namely: (1) The profile of the national goalkeeper's tactical actions in terms of the dimensions of decision making in 2019 on Indonesian Archipelago Futsal League match, (2) The profile of the national goalkeeper's tactical actions in terms of the dimensions of the goalkeeper's command in the penalties area in 2019 on Indonesian Archipelago Futsal League match, and (3) The profile of the national goalkeeper's tactical actions in 2019 on Indonesian Archipelago Futsal League. The group analysis conclusions can be further explained as follows:

1. The Profile of National Goalkeeper Tactical Actions in terms of Decision Making Dimensions at Indonesian Nusantara Futsal League.

Based on the findings in an observational study conducted on 20-22 September 2019 at Satria Krida Purwokerto Sport Center, it was found that the tactical action recapitulation that was mostly carried out by national futsal goalkeepers in the Nusantara Futsal League in 2019 was the tactical action most carried out by goalkeepers in sequence, namely when the ball is in the opposing team. The goalkeeper must always look for an opening so he can see the ball 691 times $(54.5 \%)$ by the goalkeeper, when the ball is in the goalkeeper, the goalkeeper throws the 
short ball at the defender 365 times $(37.28 \%)$ ) is performed by the goalkeeper, the goalkeeper stops the ball by hand, when the ball comes to the back of the defense is done by the goalkeeper 286 times (31.68\%), when the goalkeeper's corner kicks himself between the two players who are approaching the direction of the ball 306 times $(31.29 \%)$ taken by the goalkeeper, when a weak shot from the opponent the goalkeeper tries to catch with both hands is taken seb many 242 times (30.52\%).

Goalkeepers must be able to find gaps in order to see the ball which is the habit most often done by goalkeepers in the 2019 Nusantara Futsal League. This shows that the goalkeeper in his role as a goalkeeper must always be mobile to see the ball. In addition, because the goalkeeper is in the rear position with more and more goalkeepers looking for gaps in order to see the ball. The goalkeeper can give instructions to teammates to anticipate when the ball coming to goal. When the ball is in the goalkeeper, the goalkeeper throws the short ball at the defender 365 times $(37.28 \%)$ by the goalkeeper. Based on observations during the match, this tactical action is mostly done by goalkeepers in situations to build attacks from below. The goalkeeper stops the ball with his hands, when the ball comes to the back of his defense, it is done by the goalkeeper 286 times $(31.68 \%)$. Goalkeepers are free to use their hands to catch the ball in the penalty area to secure the ball from opponent attacks.

From the results of research on the dimensions of decision-making carried out by goalkeepers in 2019 on Nusantara Futsal League, it is appropriate manager who do their job well in managing the team and mobilizing players in certain areas. It helps their teammates to prepare for the opponent's attacks while keeping themselves alert. Such organization occurs even when the goalkeeping team has the ball. The goalkeeper keeps in touch with the players closest to him. The player must anticipate where the problem is coming from and must ensure that there are enough players in the area to prevent or quickly close down threats. It is the goalkeeper's responsibility to monitor and direct the game.

Positioning the goalkeeper properly will make it easier for the goalkeeper to block the opponent's attacks. The goalkeeper must understand where both feet stand. How far from the goal, at what angle and where is roughly the opponent is aiming if the goalkeeper is standing in the occupied position. This point is the starting point in making decisions when deciding to stay in place or move out of the nest to thwart an opponent's attacker. Here also begins the thought of deciding to jump, fly, block, ambush with hands or feet to block the ball and so on. Speed reacts to balls that change direction frequently due to deflect or other things. A rebound ball is also very unpleasant situation. Because of balls like this usually make the goalkeeper position suddenly become a dead position.

Skill to predict the game, understand and organize the defense, and anticipating an opponent's attack. By taking part in attacks, goalkeepers learn to understand how the attacks come. With this knowledge it allows the goalkeeper to block balls and passes that cross the defensive line to give opponents a clear path to goal and to recognize danger points when opponents prepare for a cross-kick. The goalkeeper must have intelligence. Game intelligence allows goalkeepers to anticipate play so they can make the right decisions, and it allows them to 
communicate with teammates where they need to move and where the goalkeeper needs help. The goalkeeper needs to understand all aspects of the game because a goalkeeper is just a player who can use all parts of the body.

2. The Profile of National Goalkeeper Tactical Actions in terms of the Dimensions of Goalkeeper Orders Outside the Penalty Area at Indonesian Nusantara Futsal League.

Based on the findings of observational studies conducted on 2022 Septermber 2019 in Satria Purwokerto Sport Center obtained the recapitulation Activities of the most tactical actions undertaken by national futsal goalkeeper in 2019 on archipelago Futsal League in terms of dimensions of the order goalkeeper outside the penalty area was tactical actions The goalkeeper did the most consecutively is the goalkeeper gave a hand signal by pointing at the opponent as a signal to guard the designated opponent 615 times $(60.35 \%)$ done by the goalkeeper. The goalkeeper used the word "left ready" "right ready" when ordering friends one team as many as 474 times $(34.23 \%)$ performed by the goalkeeper.

It is the goalkeeper's responsibility to monitor and direct the game, because the goalkeeper is not directly involved in the action, he can see what's going on and can provide clarity about where things can develop. The goalkeeper is not idle on duty just because the opponent is not threatening. But when the pressure comes and the players on the pitch lose their idea, that's when the goalkeeper has the most important role. The goalkeeper must provide a calming influence and support for the team. A tense goalkeeper will not help his exhausted team regain their composure.

Communication

means communication with the threat or defender. It is important to do this. Without good communication, the potential for miss communication between players and goalkeepers is very likely. The consequense is fatal, the goal is often broken due to situations like this. The goalkeeper is the king of the penalty box. Whoever the player, must obey the goalkeeper's orders. The goalkeeper screamed violently and scolded the players when a blunder became commonplace. The concentration of a goalkeeper, it seems as if he doesn't work every minute. When the ball is in the area of the opponent's defense, the goalkeeper will tend to stay still. But actually, when in a situation like this, a goalkeeper is better off if he remains fully concentrated in the game. Concentration since the opponent's attack has not been built will make it easier to make decisions when an attack comes.

The arrival of the ball from the opposing team that is played leads to the goalkeeper's defense sector sometimes makes all colleagues lift their spirits. But the calm, confident goalkeeper who handles the ball cleanly can muster his team and stop the opponent. A goalkeeper can rebound to a safe area or hold and shoot to buy time for his team to regain his composure, regroup and reset. Staying calm amid the chaos comes from good training.

The goalkeeper is the leader and eye for all elements; it can be teammates or opposing teams. The goalkeeper must be able to control the right situation and have good communication patterns with the team. There are two main factors of goalkeeper communication, namely; (1) 
Tone / Voice. The voice emitted by a goalkeeper in ordering teammates sometimes uses a loud, firm voice, sometimes the goalkeeper also uses symbols or gestures in the form of body language as a means of communication with his teammates, (2) Types of commands, several types of commands that goalkeepers often do are: close, ready, up, open, and press.

\section{The Profile of National Goalkeeper} Tactical Action at Indonesian Nusantara Futsal League.

Based on the findings in an observational study conducted on September 20-22 2019 at Satria Krida Purwokerto Sport Center, it was found that the most national futsal goalkeepers on National Futsal League recapitulated tactical actions in the Indonesian Futsal League in 2019 to guard the designated opponent as much as $60.35 \%$, When the ball is in the opposing team, the goalkeeper must always look for gaps so that the ball is done by the goalkeeper as much as $54.5 \%$, When the ball is at the goalkeeper, the goalkeeper throws the short ball to the defender as much as $37.28 \%$, the goalkeeper used the word "ready left" "right ready" to govern teammates as much (34.23\%), goalkeeper to stop the ball with his hands when the ball came behind the defense area of $31.68 \%$. Currently the goalkeeper's corner positions himself between the two players who approached the direction of the ball as much as 306 times $(31.29 \%)$ conceded by the goalkeeper. When a corner kick is on the left or right side, the goalkeeper orders the player to cover as many goals on his left or right side as possible 237 times (24.3\%) taken by the goalkeeper. When a corner kicks, the ball bounces over the top. and able to be reached, the goalkeeper moves away from the goal line to catch or push the ball away by the goalkeeper 81 times $(8.28 \%)$, the goalkeeper corner kicks the ball then kicks it directly towards the opposing team's goal 56 times $(5.73 \%)$ by the goalkeeper, the goalkeeper's corner kicks the ball and then kicks it directly at the opposing team's goal were 27 times (4.77\%), and when the corner kicks, the goalkeeper manages to defend were 271 times $(27.6 \%)$.

The results of this study indicate that the tactical actions of the goalkeepers in the Indonesian Archipelago Futsal League in 2019 are more dominated by the giving of hand signals by the goalkeeper to teammates. This means that in anticipating the arrival of the ball towards the goal, national goalkeepers tend to use tactical actions with nonverbal language more often. It can be assumed that to anticipate the time and movement of the ball so fast hand signals are considered more appropriate to be used in communicating with the team.

\section{CONCLUSION}

From the results of the research that has been done, there are several conclusions, namely:

1. The profile of the national goalkeeper's tactical actions in 2019 on Indonesian Archipelago Futsal League in terms of decision-making is as follows: the tactical actions that goalkeepers mostly done by the goalkeeper when the ball is in the opposing team, the goalkeeper must always look for gaps in order to see the ball as much as 691 times (54, $5 \%$ ). When the ball is on the goalkeeper, the goalkeeper throws the short ball at the defender as much as 365 times (37.28\%). The goalkeeper uses the word "left ready" "right ready" in ordering a 
teammate as much as 474 times or $(34,23 \%)$. The goalkeeper stops the ball with his hands, when the ball comes to the back of his defense as much as 286 times $(31.68 \%)$. While, the goalkeeper's corner kicks himself between the two players who are approaching the direction of the ball as much as 306 times $(31,29 \%)$. A weak shot from the opponent, the goalkeeper tries to catch the ball with both hands is done as much as 242 times $(30.52 \%)$.

2. The profile of the national goalkeeper's tactical actions in 2019 on the Indonesian Archipelago Futsal League in terms of the dimensions of the goalkeeper's orders in the penalty area that most goalkeepers do is that the goalkeeper gives a hand signal by pointing to the opponent as a signal to guard the designated opponent as much as 615 times $(60.35 \%)$. The goalkeeper used the word "left ready" "right ready" in commanding teammates as much as 474 times $(34.23 \%)$

3 . The overall profile of the national goalkeeper's tactical actions in 2019 on the Indonesian Archipelago Futsal League as a whole is the goalkeeper giving a hand signal by pointing the opponent to guard the designated opponent as much as $60.35 \%$. The goalkeeper is always looking for gaps to see the ball as much as $54.5 \%$. The goalkeeper throws the ball short $37.28 \%$ of the goalkeeper is done to the defender. The goalkeeper stops the ball by hand, when the ball arrives in the back of the defense by $31.68 \%$. The goalkeeper corners himself between the two players who are approaching the direction of the ball as much as 306 times $(31.29 \%)$. There is a corner kick on the left or right side, the goalkeeper orders the player to cover as many goals as possible on his or her left or right side as much as 237 times (24.3\%). The goalkeeper moves away from the goal line to catching or warding off the ball was done by the goalkeeper as many as 81 times $(8.28 \%)$. Then, the goalkeeper caught the ball then kicked it directly towards the opposing team's goal as much as 56 times $(5.73 \%)$. Next, Goalkeeper caught the ball and kicked it straight at the opposing team's goal as much as 27 times (4.77\%), and goalkeeper arrange defend performed a total of 271 times $(27.6 \%)$.

\section{REFERENCES}

Andrzej, S., Lipnska, P., \& Chamera, M. (2010). The Efficiency Model of Goalkeeper's Actions in Soccer. Baltic Journal of Health and Physical Activity, 2.

Bueno, M. J. de O., Caetanol, F. G., Yonezawa, M. K., Grella, A. S., Cunha, S. A., \& Moura, F. A. (2018). How do futsal players of different categories play during official matches? A tactical approach to players' organization on the court from positional data. Jurnal Plos One, 13(6). https://doi.org/10.1371/journal.pone.01 99619

Franco, F., Bores-Cerezal, A., BarcalaFurelos, R., \& Mecias-Calvo, M. (2014). Analysis of the Conducts of Elite Futsal Goalkeeper in the Different Situations of the Game. American Journal of Sports Science and Medicine, 2(3), 71-76. https://doi.org/10.12691/ajssm-2-3-1

Halim, S. (2011). Satu Hari Pintar Main Futsal. Yogyakarta:Media Pressindo.

Kramer, D. (2012). Youth Goalleeper Curriculum, Soccer Club Edge.

Lhaksana, J. (2011). Teknik dan Strategi Futsal Modern Be Champion. Swadaya Group. 
Luxbacher, A. J. (2011). Langkah-langkah Menuju Sukses Sepak Bola. Jakarta:PT Raja Grafindo Persada.

Moura, F. A., Santana, J. E., Marche, A. L., \& Aguiar, H. T. (2011). Quantitative analysis of futsal players' organization on the Court. Portuguese Journal of Sport Sciences.

Mulyono, M. A. (2014). Buku Pintar Panduan Futsal. Laskar Aksara.

Sugiyono. (2014). Metode Penelitian. Bandung:Alfabeta.

Susilo, \& Suyanto. (2015). Metodologi Penelitian Cross Sectional Kedokteran \& Kesehatan. Klate:Bossscript.

Timo, S. S. (2011). Kurikulum dan Pedoman Dasar Sepak Bola Indonesia.

Vic, H., \& Lainer, E. (2011). Futsal: Technique, Tactics and Training. Meyer And Meyer Sport.

Vicente-Vila1, P., \& Lago-Peñas, C. (2016). The Goalkeeper Influence on Ball Possession Effectiveness in Futsal. Journal of Human Kinetics, 51. https://doi.org/10.1515/hukin-20150185217

Woitalla, M. (2011). The Complete Soccer Goalkeeper. Human Kinetices. 